\title{
A facial, scalable, and green synthesis of superparamagnetic palladium-carbon catalyst and its use in disproportionation of gum rosin
}

\author{
Ramin Mostafalu ${ }^{1} \cdot$ Akbar Heydari $^{1} \cdot$ Marzban Arefi $^{1} \cdot$ Maryam Kazemi $^{1}$ \\ Abbas Banaei ${ }^{2} \cdot$ Fatemeh Ghorbani $^{2}$
}

Received: 20 April 2017/ Accepted: 12 June 2017/Published online: 22 June 2017

(c) The Author(s) 2017. This article is an open access publication

\begin{abstract}
We reported here the preparation, characterization, and catalytic ability of a $\mathrm{Fe}_{3} \mathrm{O}_{4}$-supported palladiumcarbon $\left(\mathrm{Fe}_{3} \mathrm{O}_{4}-\mathrm{Pd}-\mathrm{C}\right)$ as an efficient catalyst in disproportionation of gum rosin. The magnetic nanocatalyst was prepared by a simple method and was characterized by FTIR, XRD, TEM, $\mathrm{N}_{2}$ adsorption-desorption, VSM, and atomic absorption analysis. The prepared catalyst displayed excellent activity in disproportionation of gum rosin. The magnetic $\mathrm{Fe}_{3} \mathrm{O}_{4}-\mathrm{Pd}-\mathrm{C}$ catalyst was successfully recycled three times with keeping its catalytic performance. The simplicity of the nanocatalyst production method and simple separation and recyclability, on the other hand, make possible the industrial production and application of the catalyst.
\end{abstract}

Keywords Magnetic palladium-carbon · Palladiumcarbon - Magnetic active carbon - Disproportionated rosin (DPR) $\cdot$ Gum rosin $\cdot$ Activated carbon

\section{Introduction}

Active carbon due to high surface area, an open pore structure, excellent thermal and chemical stability, and low price is widely used as catalyst support and adsorbent, and finds extensive uses in the chemical and pharmaceuticalmanufacturing industries [1-3]. However, carbon-

Akbar Heydari

heydar_a@modares.ac.ir

1 Chemistry Department, Tarbiat Modarres University, P.O. Box 14155-4838, Tehran, Iran

2 Padideh Shimi Jam Co., Karaj, Iran supported catalysts are difficult to separate from reaction mixture and need special filtration system (Fig. 1), and then using them in large scales has been limited [4].

An attractive alternative to filtration or centrifugation is magnetic separation [5-8]. Magnetic separation method due to simplicity, high efficiency, and low cost has been widely used. In this regard, many researches are concentrating on modified active carbon [9-12]. For example, recently, Schuth et al. have reported in situ preparation of magnetic-activated carbon by formation of $\mathrm{Fe}_{3} \mathrm{O}_{4}$ nanoparticles in the pores of carbon [9]. More recently, preparation of activated maize cob coated with magnetic nanoparticles have been reported by Morad et al. for methylene blue (MB) adsorption [10]. Kakavandi et al. used magnetic-activated carbon for removal of aniline [11]. Mohan et al. used magnetic-activated carbon for tri-nitrophenol removal from aqueous solution [12]. However, in the most of these reports, magnetic active carbon is used as an absorbent, and research on modified carbon using magnetic nanoparticles as a support for application in catalytic reaction has not been reported before.

In our recently efforts, we have found that the activated carbon-supported palladium nanoparticles are an efficient nanocatalyst for the disproportionation of rosin [13]. Here in, the catalytic activity of magnetic palladium-carbon for disproportionation of rosin is reported.

\section{Experimental section}

\section{Chemicals}

All reagents and chemicals were purchased from the Daejung, Merck and Aldrich companies, and gum rosin was obtained as a gift from Padideh Shimi Jam Co. 


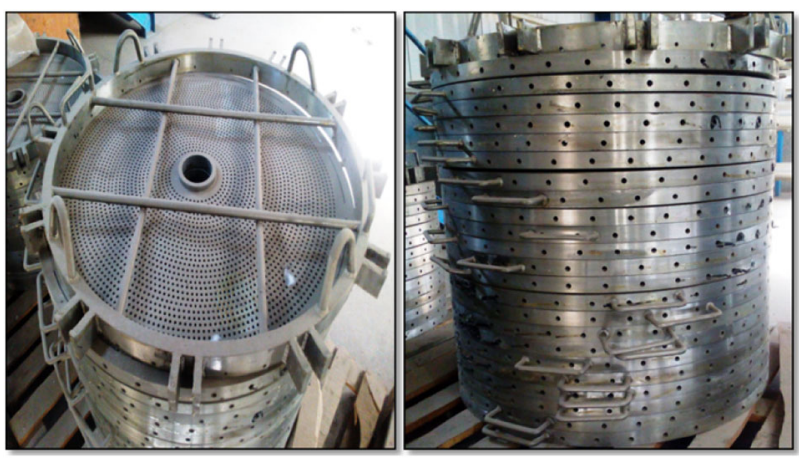

Fig. 1 Filtration system for remove palladium-carbon catalyst from reaction mixture

\section{Preparation of the activated carbon-supported palladium nanoparticles (Pd-NP-AC)}

Twenty grams of activated carbon was dispersed in $50 \mathrm{ml}$ distilled water at $80{ }^{\circ} \mathrm{C}$. One gram of palladium metal was dissolved in aqua regia $(4 \mathrm{ml})$ and added to the reaction mixture. After $2 \mathrm{~h}$, the resulting black solid was filtered and washed by the use of distilled hot water for three times. The sample was dispersed in $60 \mathrm{ml}$ distilled water, and using $2 \mathrm{M}$ sodium hydroxide solution the $p \mathrm{H}$ was increased to 9 . Next, $60 \mathrm{ml}$ formaldehyde solution (37\%) was added to the reaction. After $2 \mathrm{~h}$ at $80{ }^{\circ} \mathrm{C}$, the resulting solid was filtered and washed using hot water and dried at $105^{\circ} \mathrm{C}$.

\section{Preparation $\mathrm{Fe}_{3} \mathrm{O}_{4}$-palladium-active carbon $\left(\mathrm{Fe}_{3} \mathrm{O}_{4}-\mathrm{Pd}-\mathrm{C}\right)$}

$\mathrm{FeCl}_{3} \cdot 6 \mathrm{H}_{2} \mathrm{O}(8.7 \mathrm{mmol})$ and $\mathrm{FeCl}_{2} \cdot 4 \mathrm{H}_{2} \mathrm{O}(4.3 \mathrm{mmol})$ were dissolved in distilled water at $\mathrm{N}_{2}$ atmosphere. Subsequently, at $90{ }^{\circ} \mathrm{C}, 15 \mathrm{ml}$ ammonia $(25 \%)$ and $1 \mathrm{~g}$ of palladium-active carbon were added to the reaction mixture. After 30 min, the formed $\mathrm{Fe}_{3} \mathrm{O}_{4}-\mathrm{Pd}-\mathrm{C}$ was collected with a magnet, washed three times with distilled hot water and dried at $105{ }^{\circ} \mathrm{C}$. $\mathrm{Fe}_{3} \mathrm{O}_{4}$ nanoparticles were individually prepared according to the above procedure without adding palladium-carbon.

\section{General procedure for gum rosin disproportionation by $\mathrm{Fe}_{3} \mathrm{O}_{4}-\mathrm{Pd}-\mathrm{C}$}

In a three-neck flask fitted with a stirrer, condenser, and thermometer, $100 \mathrm{~g}$ of gum rosin was heated under $\mathrm{N}_{2}$ atmosphere. Once temperature of reaction was reached to $280^{\circ} \mathrm{C}$, and a sample was withdrawn. Subsequently, $\mathrm{Fe}_{3} \mathrm{O}_{4}-\mathrm{Pd}-\mathrm{C}$ was added to reaction flask and more samples were withdrawn every $1 \mathrm{~h}$. A gas chromatography analysis was performed for a quantitative analysis of the samples [13].

\section{Recyclability of $\mathrm{Fe}_{3} \mathrm{O}_{4}-\mathrm{Pd}-\mathrm{C}$ catalyst}

To recycle the $\mathrm{Fe}_{3} \mathrm{O}_{4}-\mathrm{Pd}-\mathrm{C}$ catalyst, the catalyst was collected by a magnet, washed with iso-propanol, and dried at $80{ }^{\circ} \mathrm{C}$.

\section{Result and discussion}

The $\mathrm{Fe}_{3} \mathrm{O}_{4}-\mathrm{Pd}-\mathrm{C}$ catalyst was prepared by a simple coprecipitation of iron precursors $\left(\mathrm{Fe}^{2+}\right.$ and $\left.\mathrm{Fe}^{3+}\right)$ and palladium-carbon (Fig. 2).

Figure 3 shows the FTIR spectra of the magnetic $\mathrm{Fe}_{3} \mathrm{O}_{4}-\mathrm{Pd}-\mathrm{C}$ in the $400-4000 \mathrm{~cm}^{-1}$ wave number range. The IR adsorption band in $567.78 \mathrm{~cm}^{-1}$ is attributed to the $\mathrm{Fe}-\mathrm{O}$ bonds. The broad band between $3000-3700 \mathrm{~cm}^{-1}$ region is attributed to the hydroxyl groups. The peaks at $1094-1571 \mathrm{~cm}^{-1}$ are ascribed to the presence of active carbon $[12,14]$. Therefore, it can be concluded that $\mathrm{Fe}_{3} \mathrm{O}_{4}$ nanoparticles were supported successfully on the palladium-carbon.

The X-ray diffraction peaks (XRD) of the $\mathrm{Fe}_{3} \mathrm{O}_{4}$ (Fig. 4) and $\mathrm{Fe}_{3} \mathrm{O}_{4}-\mathrm{Pd}-\mathrm{C}$ are presented in Fig. 5. Six strong diffraction peaks at $2 \theta=30.3,35.7,43.4,53.9,57.8$, and 63.1, which are related to the (220), (311), (400), (422), (511), and (440) phases of $\mathrm{Fe}_{3} \mathrm{O}_{4}$ (JCPDS Card no. 88-0315, $a=8.375 \AA$ ), were found in the XRD patterns of $\mathrm{Fe}_{3} \mathrm{O}_{4}$ and $\mathrm{Fe}_{3} \mathrm{O}_{4}-\mathrm{Pd}-\mathrm{C}$. In the spectra of the $\mathrm{Fe}_{3} \mathrm{O}_{4}-\mathrm{Pd}-\mathrm{C}$, narrow peaks at $2 \theta=40.1^{\circ}$ and $46.6^{\circ}$ and $67.9^{\circ}$ were related to the presence of $\mathrm{Pd}$ [15], and the mass loadings of Pd were determined to be $2.46 \% \mathrm{w} / \mathrm{w}$ by atomic absorption analysis. The broadening of the $2 \theta=10-30^{\circ}$ in the spectra of the $\mathrm{Fe}_{3} \mathrm{O}_{4}-\mathrm{Pd}-\mathrm{C}$ is related to activated carbon.

The crystal size of the $\mathrm{Fe}_{3} \mathrm{O}_{4}$ nanoparticles was calculated using Scherrer's equation [16]. The determined particle size for $\mathrm{Fe}_{3} \mathrm{O}_{4}$ nanoparticles in the $\mathrm{Fe}_{3} \mathrm{O}_{4}$ and $\mathrm{Fe}_{3} \mathrm{O}_{4}-$ $\mathrm{Pd}-\mathrm{C}$ came out to be $28 \mathrm{~nm}$ and $7.5 \mathrm{~nm}$, respectively. This reveals that during the synthesis of the $\mathrm{Fe}_{3} \mathrm{O}_{4}$ nanoparticles, $\mathrm{Pd}-\mathrm{C}$ prevents aggregation of these nanoparticles and because of that $\mathrm{Fe}_{3} \mathrm{O}_{4}$ nanoparticles loaded on activated carbon had the smallest sizes.

The lattice strain and dislocation density were $1.2 \times 10^{-3}$ and $3.9 \times 10^{-2} \mathrm{~m}^{-2}$ for $\mathrm{Fe}_{3} \mathrm{O}_{4}$ and $1.7 \times 10^{-2}$ and $1.5 \times 10^{-2} \mathrm{~m}^{-2}$ for $\mathrm{Fe}_{3} \mathrm{O}_{4}-\mathrm{Pd}-\mathrm{C}$, respectively, and were calculated from Eq. (1) and (2) where ' $D$ ' and ' $\beta$ ' are the crystallite size and the full width at half maximum (radian), respectively [16]. Small strain value indicates good crystallinity.

$$
\begin{aligned}
& \delta=\frac{1}{D^{2}} \\
& \varepsilon=\frac{\beta_{\mathrm{hkl}}}{4 \tan \theta}
\end{aligned}
$$


Fig. 2 Schematic image to preparation $\mathrm{Fe}_{3} \mathrm{O}_{4}-\mathrm{Pd}-\mathrm{C}$ catalyst

Fig. 3 FTIR spectrum of $\mathrm{Fe}_{3} \mathrm{O}_{4}-\mathrm{Pd}-\mathrm{C}$

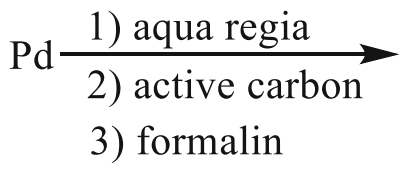
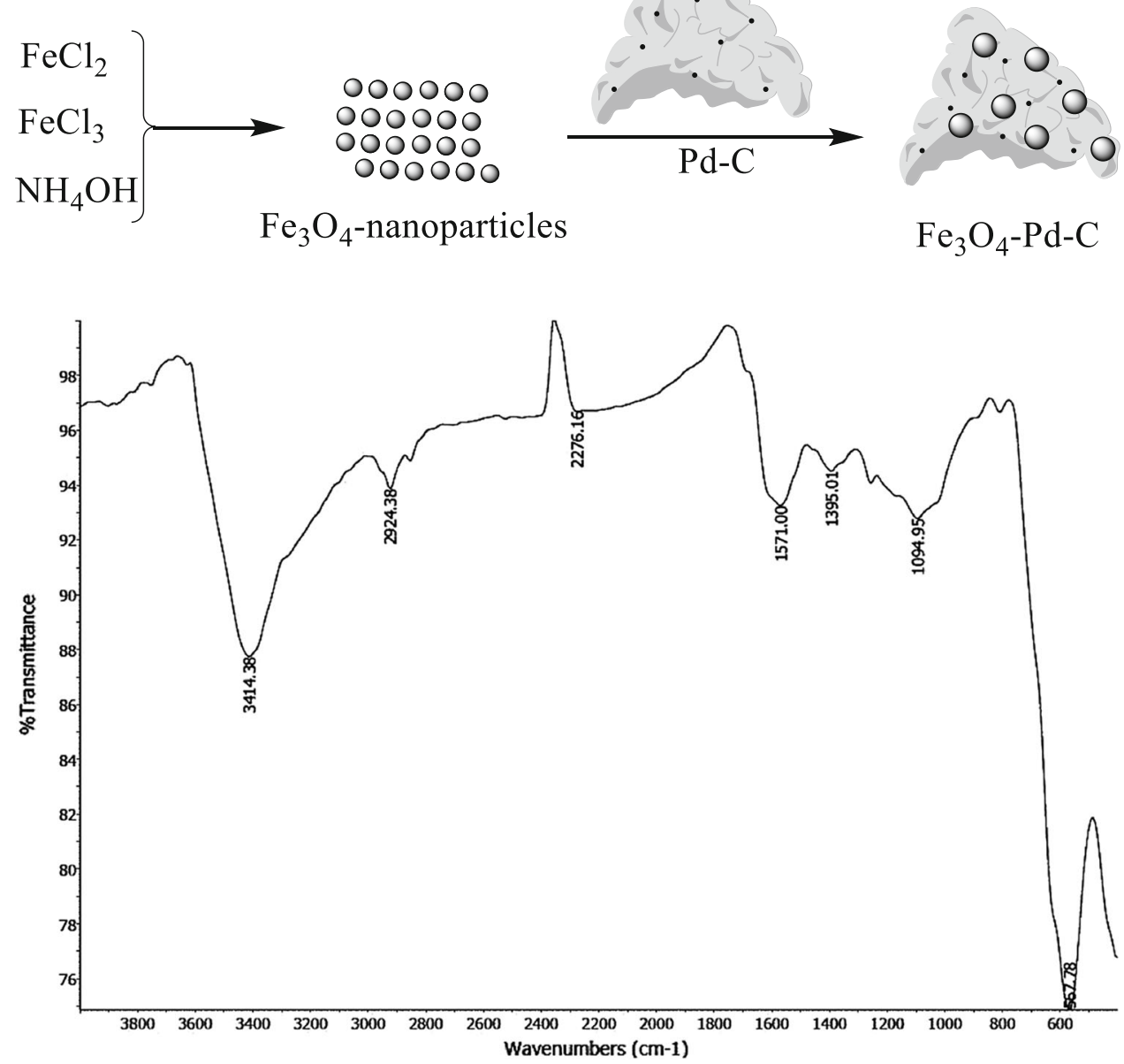

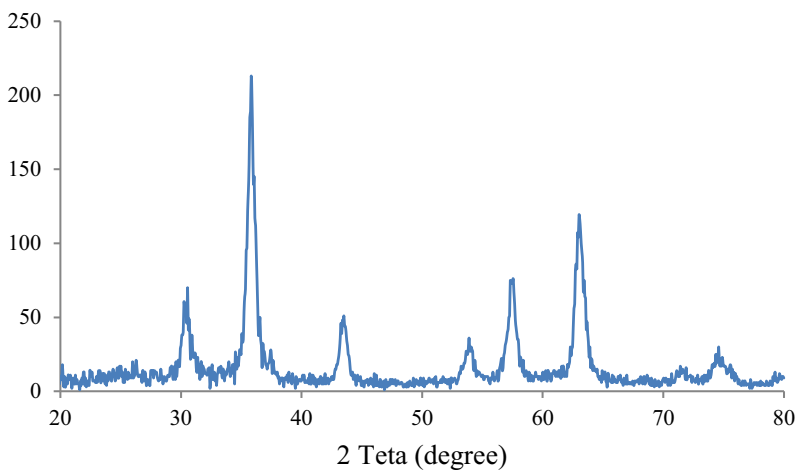

Fig. 4 XRD patterns of $\mathrm{Fe}_{3} \mathrm{O}_{4}$

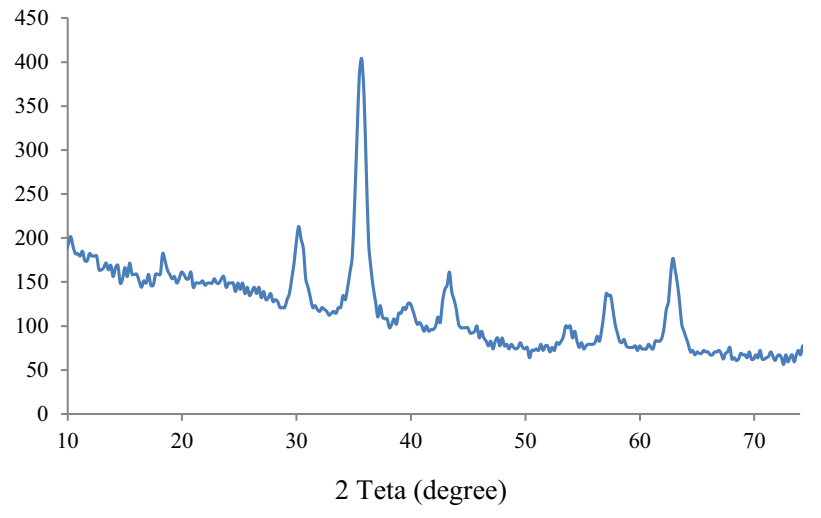

Fig. 5 XRD patterns of $\mathrm{Fe}_{3} \mathrm{O}_{4}-\mathrm{Pd}-\mathrm{C}$ 
Fig. 6 a TEM of $\mathrm{Fe}_{3} \mathrm{O}_{4}$ nanoparticles (scale $50 \mathrm{~nm}$ ) and b Palladium-carbon (scale $200 \mathrm{~nm}$ )
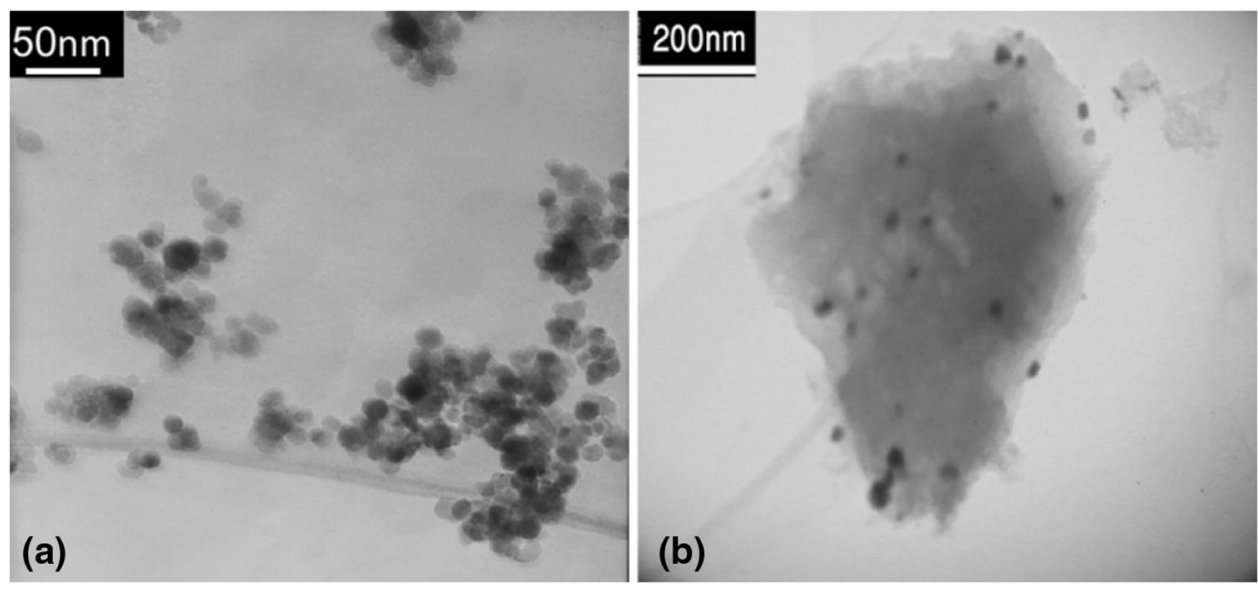

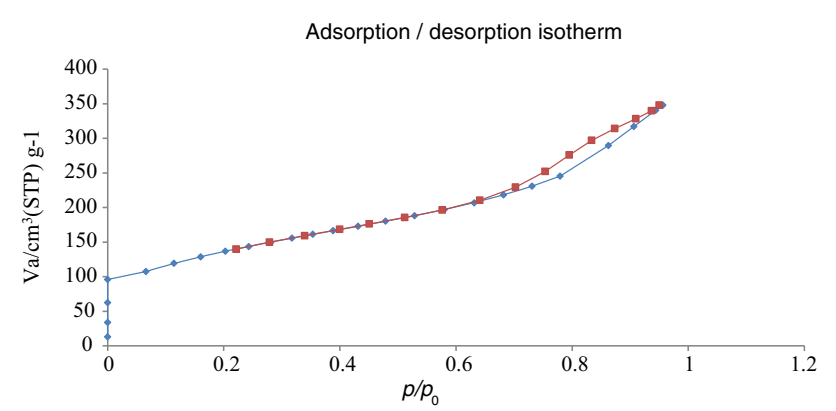

Fig. 7 Adsorption/desorption isotherm of $\mathrm{Fe}_{3} \mathrm{O}_{4}-\mathrm{Pd}-\mathrm{C}$ catalyst

Figure 6 shows the transmission electron microscopy (TEM) images of the palladium-carbon ( $\mathrm{Pd}-\mathrm{C})$ and $\mathrm{Fe}_{3} \mathrm{O}_{4}$ nanoparticles. In the TEM of $\mathrm{Pd}-\mathrm{C}$, palladium with high atomic number blocked partial electrons from TEM electron beam, and this made the palladium nanoparticles dark under TEM [5]. TEM images of $\mathrm{Pd}-\mathrm{C}$ reveal that palladium nanoparticles are well dispersed on activated carbon and the size of Pd particles is about 10-45 nm. The TEM image of $\mathrm{Fe}_{3} \mathrm{O}_{4}$ clearly shows that synthesized nanoparticles are distributed uniformly and have an average size of 10-30 nm.

The $\mathrm{N}_{2}$ adsorption-desorption isotherm of the $\mathrm{Fe}_{3} \mathrm{O}_{4}-$ $\mathrm{Pd}-\mathrm{C}$ show type IV pattern with hysteresis (H3) loops at relative pressure of $0.6-1.0$ (Fig. 7). Brunauer-EmmettTeller (BET) analysis indicated that surface area of the $\mathrm{Fe}_{3} \mathrm{O}_{4}-\mathrm{Pd}-\mathrm{C}$ is $487.7 \mathrm{~m}^{2} / \mathrm{g}$, while total pore volume is $0.0407 \mathrm{~cm}^{3} / \mathrm{g}$. The pore size diameter was calculated be $2.582 \mathrm{~nm}$. The high surface area $\left(487.7 \mathrm{~m}^{2} / \mathrm{g}\right)$ may be beneficial to enhancing the catalytic activity of $\mathrm{Fe}_{3} \mathrm{O}_{4}-\mathrm{Pd}-$ C catalyst.

The magnetically controllable aggregation behavior of $\mathrm{Fe}_{3} \mathrm{O}_{4}-\mathrm{Pd}-\mathrm{C}$ was investigated by vibrating sample magnetometer (VSM) studies. Figures 8 and 9 show the VSM curves of the $\mathrm{Fe}_{3} \mathrm{O}_{4}$ and $\mathrm{Fe}_{3} \mathrm{O}_{4}-\mathrm{Pd}-\mathrm{C}$, respectively,

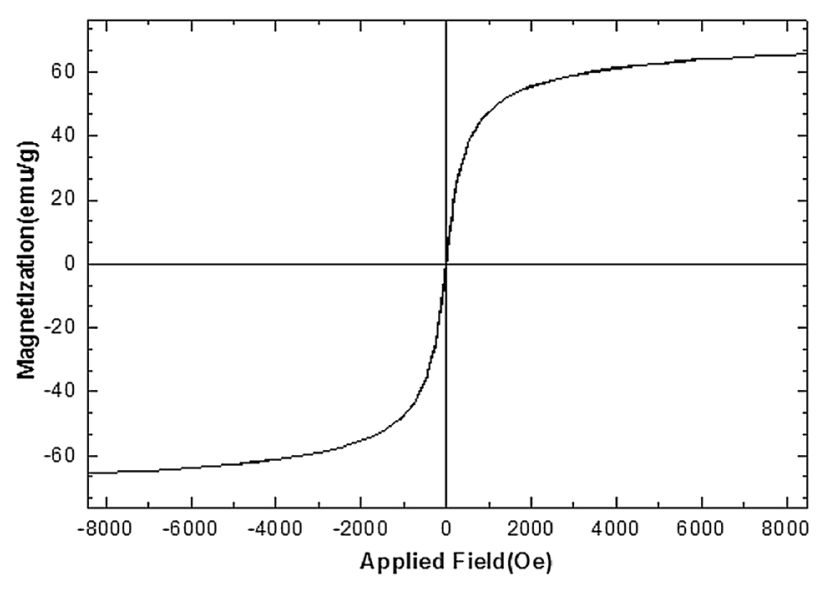

Fig. 8 VSM curve of the $\mathrm{Fe}_{3} \mathrm{O}_{4}$ nanoparticles

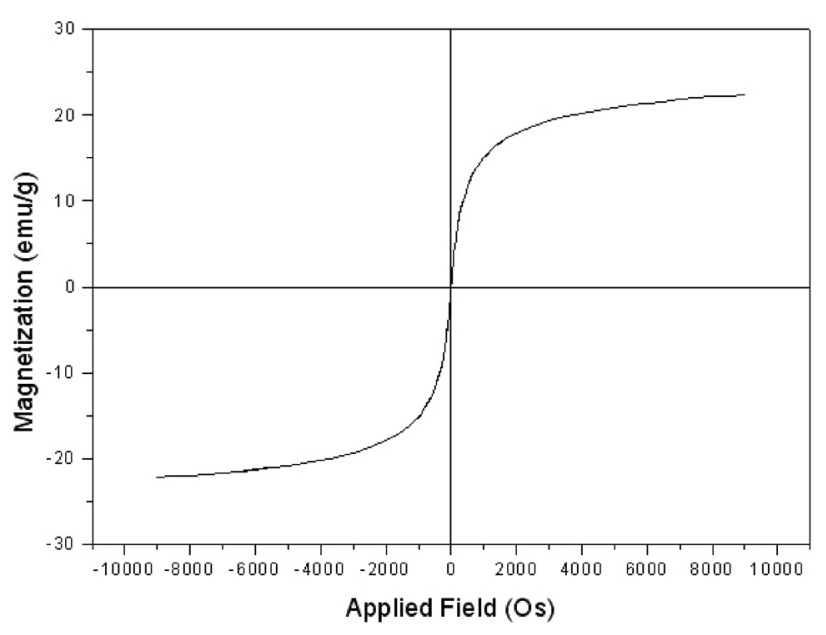

Fig. 9 VSM curve of the $\mathrm{Fe}_{3} \mathrm{O}_{4}-\mathrm{Pd}-\mathrm{C}$ catalyst

measured by the Meghnatis Daghigh Kavir Company (Iran). $\mathrm{Fe}_{3} \mathrm{O}_{4}$ and $\mathrm{Fe}_{3} \mathrm{O}_{4}-\mathrm{Pd}-\mathrm{C}$ show superparamagnetic behavior, and the saturation magnetization was determined to be 65.5 and $25.0 \mathrm{emu} \mathrm{g}^{-1}$, respectively. 


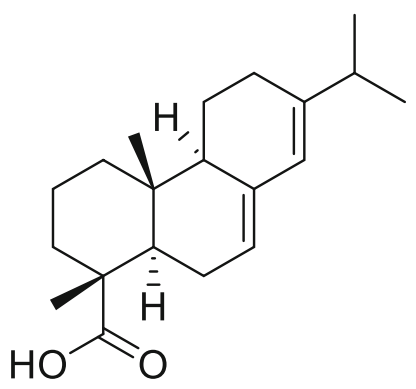

Fig. 10 Chemical structure of abietic acid

Table 1 Reusability test of catal

\begin{tabular}{lll}
\hline DAA \% First run & DAA \% Second run & DAA \% Third run \\
\hline 74 & 69.5 & 68 \\
\hline
\end{tabular}

Gum rosin is one of the important renewable forestry products and approximately $90 \%$ of the gum rosin is the abietic-type resin acid with a conjugated double bond (Fig. 10) [17]. By the use of a catalytic disproportionation reaction, the highly reactive conjugated double bond in abietic-type resin acid can be modified. Due to its advantages, i.e., high oxidation resistance, high softening point, low brittleness, and very good color stability, disproportionated rosin (DPR) has proved to be superior quietly to rosin in many applications.

Here in, the catalytic activity of $\mathrm{Fe}_{3} \mathrm{O}_{4}-\mathrm{Pd}-\mathrm{C}$ in the synthesis of DPR from gum rosin was studied, and the reaction was checked by gas chromatography (GC) analysis [13]. A control experiment showed that $\mathrm{Fe}_{3} \mathrm{O}_{4}$ and $\mathrm{Fe}_{3} \mathrm{O}_{4}-$ active carbon could not catalyze this disproportionation reaction, and the presence of palladium is essential. When the reaction was carried out with $\mathrm{Fe}_{3} \mathrm{O}_{4}-\mathrm{Pd}-\mathrm{C}(0.1 \%$ w/w $)$, dehydroabietic acid was obtained in $65 \%$ yield after $6 \mathrm{~h}$. If the reaction temperature is decreased from 280 to $220{ }^{\circ} \mathrm{C}$, dehydroabietic acid will obtain in $19.6 \%$ yield. After evaluation of the catalytic activity of $\mathrm{Fe}_{3} \mathrm{O}_{4}-\mathrm{Pd}-\mathrm{C}$, optimization shows that the best result was obtained by using of $0.25 \%$ w/w of $\mathrm{Fe}_{3} \mathrm{O}_{4}-\mathrm{Pd}-\mathrm{C}$ with an optimal reaction temperature of $280^{\circ} \mathrm{C}$. In this condition, dehydroabietic acid was obtained in $74 \%$ yield after $1 \mathrm{~h}$.

To recycle the $\mathrm{Fe}_{3} \mathrm{O}_{4}-\mathrm{Pd}-\mathrm{C}$ catalyst, the magnetic catalyst was collected by a magnet, washed with iso-propanol for three times, and dried. At least, the $\mathrm{Fe}_{3} \mathrm{O}_{4}-\mathrm{Pd}-\mathrm{C}$ catalyst was stable and reusable for three reaction runs (Table 1).

\section{Conclusions}

In conclusion, the catalytic disproportionation of gum rosin over a magnetic palladium-carbon $\left(\mathrm{Fe}_{3} \mathrm{O}_{4}-\mathrm{Pd}-\mathrm{C}\right)$ was investigated. The catalyst obtained via the pathway described in this manuscript is essentially superparamagnetic, has high porosities and high surface areas, and displayed suitable activity in disproportionation of gum rosin. The $\mathrm{Fe}_{3} \mathrm{O}_{4}-\mathrm{Pd}-\mathrm{C}$ catalyst was stable and reusable for at least three reaction runs. Such findings are important because the simplicity of the nanocatalyst production method and simple separation and recyclability on the other hand make possible the industrial production and application of the catalyst.

Acknowledgements We are thanks the INSF (Iran National Science Foundation), Tarbiat Modares University and Padideh Shimi Jam Co. for supporting of this work.

Open Access This article is distributed under the terms of the Creative Commons Attribution 4.0 International License (http://crea tivecommons.org/licenses/by/4.0/), which permits unrestricted use, distribution, and reproduction in any medium, provided you give appropriate credit to the original author(s) and the source, provide a link to the Creative Commons license, and indicate if changes were made.

\section{References}

1. Marsh, H., Reinoso, F.R.: Activated carbon. Elsevier, Amsterdam (2006)

2. Edward, L.K., Ko, D.C., McKay, G.: Production of active carbons from waste tyres-a review. Carbon 42, 2789-2805 (2004)

3. Vijayakumar, P., Senthil Pandian, M., Pandikumar, A., Ramasamy, P.: A facile one-step synthesis and fabrication of hexagonal palladium-carbon nanocubes $(\mathrm{H}-\mathrm{Pd} / \mathrm{C} \mathrm{NCs})$ and their application as an efficient counter electrode for dye-sensitized solar cell (DSSC). Ceram. Int. 43, 8466-8474 (2017)

4. Holade, Y., Ege, N., Karine, S., Teko, S., Napporn, W., Kokoh, K.B.: Recent advances in carbon supported metal nanoparticles preparation for oxygen reduction reaction in low temperature fuel cells. Catalysts 5, 310-348 (2015)

5. Lu, A.H., Salabas, E.L., Ferdi, S.: Magnetic nanoparticles: synthesis, protection, functionalization, and application. Angew. Chem. Int. Ed. 46, 1222-1244 (2007)

6. Karimi, B., Mansouri, F., Mohammad Mirzaei, H.: Recent applications of magnetically recoverable nanocatalysts in $\mathrm{C}-\mathrm{C}$ and $\mathrm{C}-\mathrm{X}$ coupling reactions. ChemCatChem. 7, 1736-1789 (2015)

7. Faraji, M., Yamini, Y., Rezaee, M.: Magnetic nanoparticles: synthesis, stabilization, functionalization, characterization, and applications. J. Iran. Chem. Soc. 7, 1-37 (2010)

8. Arefi, M., Saberi, D., Karimi, M., Heydari, A.: Superparamagnetic $\mathrm{Fe}(\mathrm{OH})_{3} @ \mathrm{Fe}_{3} \mathrm{O}_{4}$ nanoparticles: an efficient and recoverable catalyst for tandem oxidative amidation of alcohols with amine hydrochloride salts. ACS Comb. Sci. 17, 341-347 (2015)

9. Schwickardi, M., Olejnik, S., Salabas, E. L., Schmidt, W., Schuth, F.; Scalable synthesis of activated carbon with superparamagnetic properties. Chem. Commun. 3987-3989 (2006)

10. Tan, K.A., Morad, N., Teng, T.T., Norli, I., Panneerselvam, O.: Removal of cationic dye by magnetic nanoparticle $\left(\mathrm{Fe}_{3} \mathrm{O}_{4}\right)$ impregnated onto activated maize cob powder and kinetic study of dye waste adsorption. APCBEE Procedia 1, 83-89 (2012)

11. Kakavandi, B., Jonidi, A., Rezaei, R., Nasseri, S., Ameri, A., Esrafily, A.: Synthesis and properties of $\mathrm{Fe}_{3} \mathrm{O}_{4}$-activated carbon magnetic nanoparticles for removal of aniline from aqueous solution: equilibrium, kinetic and thermodynamic studies. Iran. J. Environ. Health. Sci. Eng. 10, 19 (2013) 
12. Mohan, D., Sarswat, A., Singh, V.K., Alexandre Franco, M., Pittman, C.U.: Development of magnetic activated carbon from almond shells for trinitrophenol removal from water. Chem. Eng. J. 172, 1111-1125 (2011)

13. Mostafalu, R., Hydari, A., Banaei, A., Ghorbani, F., Arefi, M.: The use of palladium nanoparticles supported on active carbon for synthesis of Disproportionate rosin (DPR) as a useful emulsifier in petrochemical industries. J. Nanostruct. Chem. 7, 61-66 (2016)

14. Ríos-Hurtado, J.C., Múzquiz-Ramos, E.M., Zugasti-Cruz, A., Cortés-Hernández, D.A.: Mechano ynthesis as a simple method to obtain a magnetic composite (activated carbon/ $\mathrm{Fe}_{3} \mathrm{O}_{4}$ ) for hyperthermia treatment. J. Biomater. Nanobiotechnol. 7, 19-28 (2016)
15. Zamani, F., Hosseini, S.M.: Palladium nanoparticles supported on $\mathrm{Fe}_{3} \mathrm{O}_{4}$ /amino acid nanocomposite: highly active magnetic catalyst for solvent-free aerobic oxidation of alcohols. Catal. Commun. 43, 164-168 (2014)

16. Vijayakumar, P., SenthilPandian, M., Su Pei, L., Pandikumar, A., Ming, H. N., Mukhopadhyay, S., Ramasamy, P.; Investigations of tungsten carbide nanostructures treated with different temperatures as counter electrodes for dye sensitized solar cells (DSSC) applications, Mater. Sci. Mater. Electron. 26, 7977-7986 (2015)

17. Wang, L., Chen, X., Sun, W., Liang, J., Xu, X., Tong, Z.: Kinetic model for the catalytic disproportionation of pine oleoresin over Pd/C catalyst. Ind. Crop. Prod. 49, 1-9 (2013) 